\title{
THE INFLUENCE OF THE TECHNICAL CONDITION OF A BUILDING ON THE PROPERTY'S MARKET VALUE
}

Beata Ziembicka, M.Sc., Eng.

University of Szczecin

Faculty of Economics and Management

Institute of Econometrics and Statistics

Mickiewicza 64, 71-101 Szczecin, Poland

e-mail: operaty@wp.pl

Received 8 November 2015, Accepted 11 June 2016

\begin{abstract}
The housed property's market value is influenced by a set of characteristic qualities, among which is the technical condition of a building. The aim of this paper is to study the influence of the technical condition of a building on the market price of the dwelling units, depending, among others, on the chosen method and the approach to the assessment of the housing wear degree. The analysis has been performed based on the estimation of the market value of an illustrative dwelling unit located in a building erected with the use of prefabricated large panel technology in selected variants. The study is based on data from the period between January and December 2012, which are related to the sale of rights to dwelling units from the secondary market. The information was obtained from a transactional database based on the Partner Data Exchange system with the Walor software.
\end{abstract}

Keywords: property value, technical wear of buildings, dwelling buyers' preferences, dwelling quality

JEL classification: R31 


\section{Introduction}

As time flies, the structure of a building changes contributing to a reduced use value of the whole building or its part. This has influence on a potential buyer's decision, who is willing to pay for the right to a given property only as much as it assesses its condition. For a housed property or a retail property, the condition of the building is one of the features that influence a transaction price. Due to the fact that market research, including the knowledge of transaction prices, is important in estimating the market value of a property, it is therefore a real estate appraiser's task to mark significant features that influence the final value and the adoption of an appraisal method, including the approach to determining the degree of the technical wear of the building.

This issue is the subject matter of the undertaken research, that aims at assessing the influence of the technical condition of a building on the market value of a retail property, from a practical point of view. By applying the commonly used methods of assessing the degree of technical wear, this paper verified the research hypothesis about the influence of a differentiated assessment of the technical condition of a building on the property's market value. This value was estimated by means of a comparative approach using the pair comparing method on the basis of an example dwelling building. The choice of the subject and the area of the research were based on the collected data from the period between January and December 2012 (63 transactions of a cooperative ownership right to premises) concerning residential apartments in high buildings erected in the 1970's and the 1980's in a large panel technology in the Kalina and Przyjaźni housing estates.

The information was obtained from the Walor transactional database compiled based on notarial agreements on the sales of rights to residential apartments.

\section{Market characteristics and their influence on the market value of the property}

The market value of the property is determined in a comparative approach using a pair comparison method, an average price adjustment, or a statistical analysis. The assumptions for using the comparative approach, in addition to the transaction prices for properties similar to the estimated one, and the conditions of a transaction, also provide the knowledge of characteristics that influence price differentials. The weights of the characteristics can be determined in various ways, including, for example, a percentage difference between the highest and the lowest prices of the collected set of the transaction prices for the properties similar to those taken for comparison. The determined grading scale for a single characteristic depends on the market state, and can 
be the result of observing potential buyers' preferences, the analogy to similar markets (due to the area and type), or the result of the analysis of the collected information about the prices and characteristics in the area defined for the purposes of the appraisal. Other methods considered reliable are acceptable as well. The catalogue of characteristics adopted for comparison is open, and their list is set out in the Regulation of the Council of Ministers dated 29 June 2005 on real estate common appraisal. Therefore, the characteristics affecting the transaction price include the location of the building, type of the building, usage type, installation equipment, or degree of wear. The catalogue of characteristics is not exhausted, and can be extended on the basis of the results of the market analysis including: market type (e.g. residential or service premises, land market), market area (e.g. province, district, municipality, city, district, housing estate), period of analysis (e.g. two years, one year, half a year, a quarter), and microeconomic factors (e.g. demand-supply, demographic factors, level of unemployment). It is worth remembering that the source of the research can only be the transaction prices and the contractual conditions contained in the notarial acts, whereas other information is collected from other available sources, e.g. registrations of land, buildings, premises, records of monuments (Ziembicka, 2013), and based on the appraiser's own analysis - after a conducted field inspection (PKZW NI1, 2014). The mutual interaction of the 'bundle' of characteristics affects the accuracy of the appraisal, and a poor representation of the property prices in the characteristics may contribute to a poor accuracy of the appraisal. According to Kucharska-Stasiak (2010), for retail properties it is the age of the building in which the comparative premises are located that explains approximately $20 \%$ of the variation in the prices of residential dwellings. The author refers to the research by Żelazowski (Kucharska-Stasiak, 2010), who on the basis of the regression analysis justified a small - approximately $1.2 \%$ - influence of the size characteristic of the dwelling and the upstairs location on the price distribution, and explained the differentiation of prices in the amount of $5 \%$ with the characteristic related to the size of the usable space. It can be concluded from the aforementioned that the price distribution of characteristics can be difficult to conduct regardless of the method used (in the comparative approach). In the further part of the paper, the author reviews the methods known from literature that allow to determine the degree of technical wear, and leaves this subject open for further analysis.

\section{Selected methods of determining the degree of technical wear of buildings}

The literature on the subject describes many methods of determining the degree of technical wear. The most commonly used (Table 1) are based on the flow of time of use (t), 
as the most important indicator, and the expected life of a building (T). The average weighted method is equally often used, and its essence consists in assigning given elements of a building a specific importance in the importance of the entire structure.

Table 1. Selected methods of determining the degree of technical wear of buildings

\begin{tabular}{|c|l|c|}
\hline Item & \multicolumn{1}{|c|}{ Time method } & Formula \\
\hline 1 & Linear & $S_{Z T}=\frac{t}{T} \cdot 100 \%$ \\
\hline 2 & Ross's & $S_{Z T}=\frac{t \cdot(t+T)}{2 \cdot T^{2}} \cdot 100 \%$ \\
\hline 3 & Romsterfen's & $S_{Z T}=\frac{t \cdot(2 \cdot t+T)}{3 \cdot T^{2}} \cdot 100 \%$ \\
\hline 4 & Eytelwein's & $S_{Z T}=\frac{t^{2}}{T^{2}} \cdot 100 \%$ \\
\hline 5 & Average weighted method & $S_{Z T}=\sum_{i=1}^{n} \frac{U_{s i} \cdot S_{z t e_{i}}}{100} \cdot 100 \%$ \\
\hline
\end{tabular}

where:

$\mathrm{t} \quad-$ age of building in years/time of use,

$\mathrm{T}$ - expected life in years,

$\mathrm{U}_{\mathrm{ei}}$ - percentage participation of the costs of reconstruction of the $i$-th element of the building in the structure of the entire building,

$\mathrm{S}_{\text {ztei }}$ - percentage degree of consumption of a given element determined through visual inspection

$\mathrm{n}-$ number of assessed elements in the building,

i - another element.

Source: own elaboration based on Bajno (2013).

The biggest problem in determining the degree of technical wear is usually associated with the so-called concealed system (Foryś, 2008). Another dilemma is the adoption of a justified grading scale, considering the technical wear of given elements of a building. The methods presented allow to describe the process of wear in a theoretical manner (arithmetic). In fact, the design and material solutions should be adjusted to the real conditions of use and exploitation (with regard to the influence of weather conditions), but also to deviations from the project or workmanship quality.

The technical wear run for the assumed durability of 100 years, depending on the adopted time method, is presented in Figure 1, which shows that the lowest values can be achieved using Eytelwein's method (particularly well-run maintenance management), and the largest - using a linear method (inadequate maintenance management). 


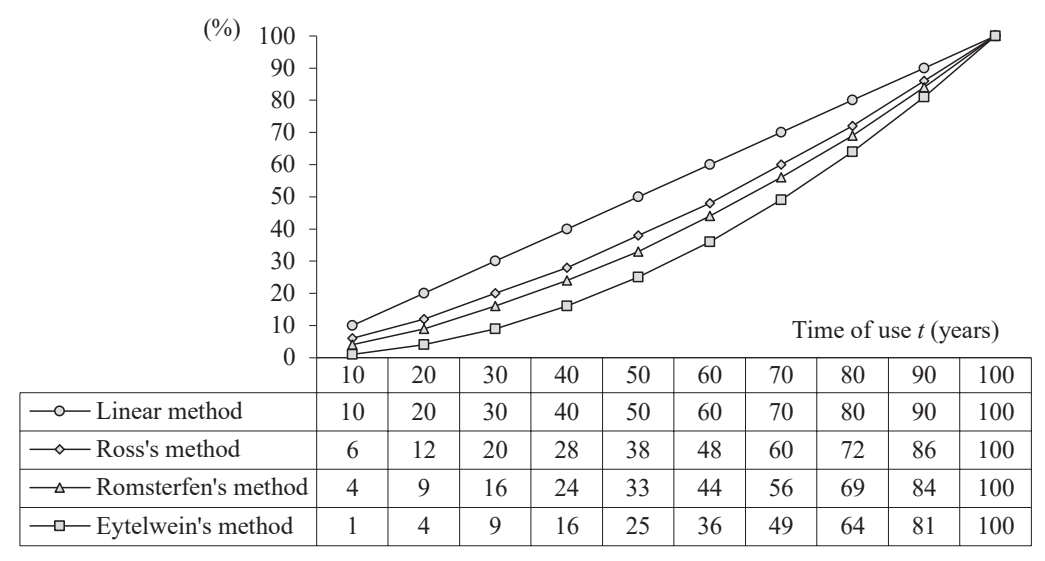

Figure 1. A comparison of time methods of determining the technical wear factor Source: own elaboration based on Bajno (2013).

Another method, the average weighted, is based on dividing a building into groups of elements and assigning them a certain weight on the basis of the pyramid of importance (Figure 2).Therefore, the technical assessment includes the division of the groups into states of progress (zero state, raw state, finishing elements, internal installations), and taking into account the quota share in the replacement value of the entire building, using the ready-made scale of percentage wear available in literature (Baranowski, 2000).

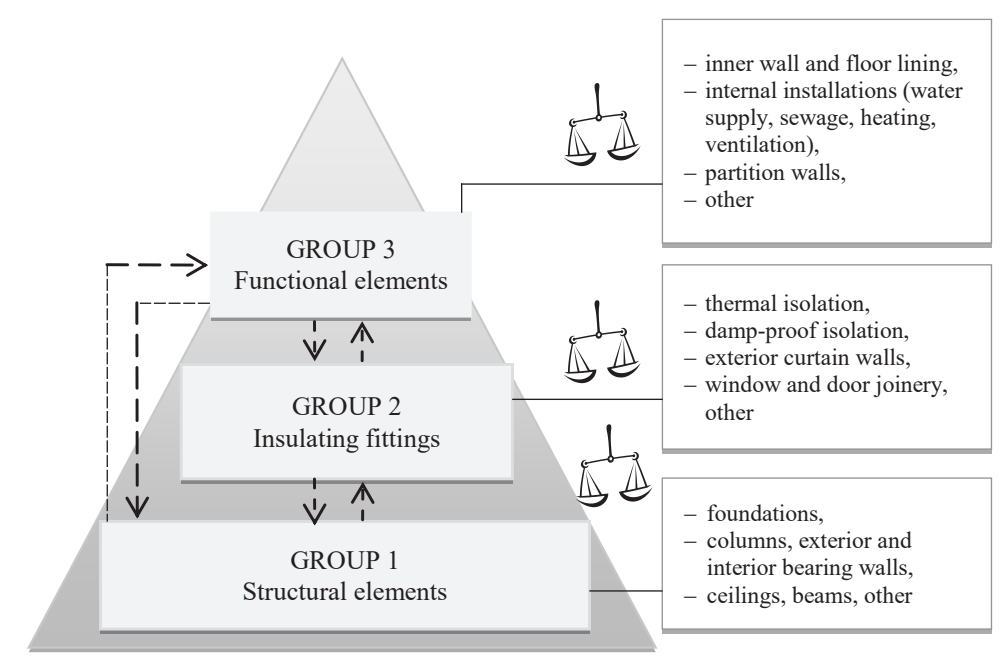

Figure 2. Criteria for establishing weights of building elements in the average weighted method Source: own elaboration. 


\section{Analysis of the influence of the technical condition of a building on the market value of a sample residential building}

On the example of a prefabricated building erected in 1979 in the area of the Kalina housing estate in Szczecin, the market value of a two-room residential apartment, with a usable area of $42.3 \mathrm{~m}^{2}$, located in the building was estimated. The appraisal was made assuming the characteristics and the weights of characteristics accepted on the basis of preferences of the clients of the real estate agencies on the local market (Table 2). The data was collected for the period between January and December 2012, and concerned the Przyjaźni and the Kalina housing estates. 63 transactions concerning residential apartments (of a cooperative ownership right to premises) located in high buildings, i.e. skyscrapers built in prefabricated technology (industrialized), were recorded.

The assessment of the degree of technical wear was made based on building No. 1131 (BCO, the second quarter of 2012) in which the greatest share $-60 \%$ of the replacement value of the building - relates to the raw state of the building, which also houses the load-bearing structure.

Table 2. Criteria for the assessment of variants of characteristics that evaluate the transaction prices on the studied market of cooperative ownership rights to residential apartments

\begin{tabular}{|c|c|c|c|}
\hline Item & Market characteristic & $\begin{array}{c}\text { Weight } \\
\text { of characteristic }(\%)\end{array}$ & Assessment \\
\hline \multirow{3}{*}{1} & \multirow{3}{*}{ Location and surroundings } & \multirow{3}{*}{5} & very good (the area is closer to 26 Kwietnia Street) \\
\hline & & & good (intermediate location) \\
\hline & & & average (the area is closer to Derdowskiego Street) \\
\hline \multirow{3}{*}{2} & \multirow{3}{*}{ Location on the floor } & \multirow{3}{*}{30} & very good (1st floor) \\
\hline & & & good (intermediate) \\
\hline & & & average (ground floor and the last floor) \\
\hline \multirow{3}{*}{3} & \multirow{3}{*}{ Area } & \multirow{3}{*}{35} & large (above $55 \mathrm{~m}^{2}$ ) \\
\hline & & & average (above $40-55 \mathrm{~m}^{2}$ ) \\
\hline & & & small (up to $40 \mathrm{~m}^{2}$ ) \\
\hline \multirow{3}{*}{4} & \multirow{3}{*}{$\begin{array}{l}\text { Technical condition of the } \\
\text { building }\end{array}$} & \multirow{3}{*}{30} & $\operatorname{good}\left(\mathrm{S}_{\mathrm{ZT}} 11 \div 20 \%\right)$ \\
\hline & & & satisfactory $\left(\mathrm{S}_{\mathrm{ZT}} 21 \div 30 \%\right)$ \\
\hline & & & average $\left(\mathrm{S}_{\mathrm{ZT}} 31 \div 50 \%\right)$ \\
\hline
\end{tabular}

Source: own elaboration.

Assuming the durability of the building of 100 years, and the period of use of 33 years, the technical wear rate was assessed using five time methods and the average weighted method in three approaches, i.e. without replacement of components during the period of use, and with the replacement of insulation and functional elements. The final approach concerned the average 
weighted method by treating the use of specific groups of elements in the function of time individually. The analysis results are shown in Figure 3.

A further assessment of the technical condition assumed the degree of technical wear, based on the average weighted method in the function of time taking into account the onetime replacement of elements in group 2 (window joinery, roofing), and in group 3 (internal installations) in the current period of use.

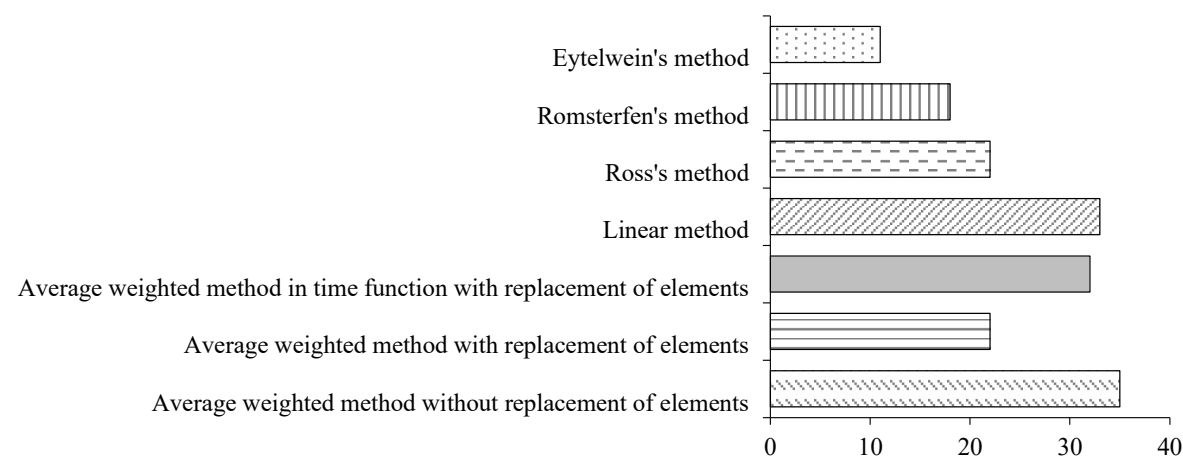

Figure 3. The degrees of technical wear $S_{Z T}$ of the building depending on the applied calculation method $(\%)$

Source: own elaboration.

Ultimately, the degree of technical wear was estimated at $32 \%$. The criteria for assessing the technical condition (Table 3 ) were adopted based on a six-stage division of the degree of technical wear.

Table 3. Criteria for assessing the technical condition of the building depending on the degree of technical wear

\begin{tabular}{|l|c|}
\hline \multicolumn{1}{|c|}{ Technical condition } & Degree of technical wear $\mathrm{S}_{\mathrm{ZT}}(\%)$ \\
\hline Very good & up to 10 \\
\hline Good & $11 \div 20$ \\
\hline Satisfactory & $21 \div 30$ \\
\hline Average & $31 \div 50$ \\
\hline Poor & $51 \div 70$ \\
\hline Very bad (emergency) & above 70 \\
\hline
\end{tabular}

Source: own elaboration. 
After analysing the local market of large-panel buildings erected in the 1970's and 1980's of the last century, the technical condition of the compared buildings was limited to good, satisfactory, and average. The apartment was assessed in terms of the characteristic qualities, and in the comparative approach, the pair comparing method was used to appraise the market value of the building which amounted to PLN 164,000, i.e. the unit value of approximately PLN 3,890.00 (Table 4). A further analysis was made based on four different comparative variants for different assessments of the technical condition of the building (Table 5), and an attempt was made to assess the influence of the technical condition on the market value of the sample building.

Table 4. Appraising the market value of a cooperative ownership right to a residential apartment located in Szczecin at Derdowskiego Street

\begin{tabular}{|c|c|c|c|c|c|c|c|c|c|}
\hline \multirow[b]{2}{*}{$\begin{array}{l}\text { Descrip } \\
\text { tion }\end{array}$} & \multirow{2}{*}{$\begin{array}{l}\text { Weight } \\
\text { of } \\
\text { charac- } \\
\text { teristic } \\
(\%)\end{array}$} & \multirow{2}{*}{$\begin{array}{c}\text { Scope } \\
\text { of quota } \\
\left(\mathrm{PLN} / \mathrm{m}^{2}\right)\end{array}$} & \multirow{2}{*}{$\begin{array}{l}\text { Apart } \\
\text { mentap- } \\
\text { prai } \\
\text { sed by }\end{array}$} & \multicolumn{6}{|c|}{ COMPARATIVE APARTMENTS } \\
\hline & & & & 1 & Corr. & 2 & Corr. & 3 & Corr. \\
\hline $\begin{array}{l}\text { Date of trans- } \\
\text { action }\end{array}$ & & & & 01.2012 & & 07.2012 & & 11.2012 & \\
\hline $\begin{array}{l}\text { Market price } \\
(\mathrm{PLN})\end{array}$ & & & & 170,000 & & 150,000 & & 165,000 & \\
\hline $\begin{array}{l}\text { Unit price } \\
\left(\mathrm{PLN} / \mathrm{m}^{2}\right)\end{array}$ & & & & $4,089.83$ & & $3,597.12$ & & $3,956.83$ & \\
\hline $\begin{array}{l}\text { Apart } \\
\text { ment surface } \\
\left(\mathrm{m}^{2}\right)\end{array}$ & & & & 42.3 & & 41.7 & & 41.7 & \\
\hline $\begin{array}{l}\text { Location } \\
\text { and the sur- } \\
\text { round dings }\end{array}$ & 5 & 104.72 & average & average & 0 & average & 0 & average & 0 \\
\hline $\begin{array}{l}\text { Location } \\
\text { on the floor }\end{array}$ & 30 & 628.27 & $\begin{array}{c}\text { good } \\
\text { (5th } \\
\text { floor) }\end{array}$ & verygood & -314.14 & good & 0 & average & 314.14 \\
\hline $\begin{array}{l}\text { Apartment } \\
\text { surface }\end{array}$ & 35 & 732.98 & $\begin{array}{c}\text { average } \\
\left(42.3 \mathrm{~m}^{2}\right)\end{array}$ & average & 0 & average & 0 & average & 0 \\
\hline $\begin{array}{l}\text { Technical } \\
\text { condition } \\
\text { of the build- } \\
\text { ing }\end{array}$ & 30 & 628.27 & $\begin{array}{l}\text { average } \\
(32 \%)\end{array}$ & average & 0 & average & 0 & average & 0 \\
\hline Total & 100 & $2,094.24$ & & & & & & & \\
\hline \multicolumn{4}{|c|}{ Total corrections (PLN) } & & -314.14 & & 0 & & 314.14 \\
\hline \multicolumn{4}{|c|}{ Correctedprice (PLN) } & & $3,775.70$ & & $3,597.12$ & & $4,270.97$ \\
\hline \multicolumn{4}{|c|}{ Averageprice (PLN) } & & & & $3,881.26$ & & \\
\hline \multicolumn{2}{|c|}{ Market value } & \multicolumn{8}{|c|}{$\mathrm{W}_{\mathrm{r}}=3,881.26 \mathrm{PLN} \times 42.30 \mathrm{~m}^{2}=164,177 \mathrm{PLN}$} \\
\hline
\end{tabular}

Source: own elaboration. 
Table 5. Technical condition variants accepted for comparison

\begin{tabular}{|l|l|}
\hline \multicolumn{1}{|c|}{ Variant } & \multicolumn{1}{c|}{ Description } \\
\hline basic & $1,2,3$ - average technical condition \\
\hline I & $1,2,3$ - satisfactory technical condition \\
\hline II & 1,2 - satisfactory technical condition, 3-good technical condition \\
\hline III & $1,2-$ good technical condition, 3 - satisfactory technical condition \\
\hline IV & $1,2,3$ - good technical condition \\
\hline
\end{tabular}

Where: 1, 2, 3-comparative apartments.

Source: own elaboration.

The assessment of the technical condition of the property is made by an appraiser, and the subjectivity of the assessment may affect the results for the assumed variants (Table 6).

Table 6. Market value $W_{r}$ (PLN) depending on the adopted variant of assessment of the technical condition of the building

\begin{tabular}{|c|c|c|c|c|}
\hline Basic variant & Variant I & Variant II & Variant III & Variant IV \\
\hline 164,177 & 150,891 & 146,461 & 142,032 & 137,603 \\
\hline
\end{tabular}

Source: own elaboration.

The above calculations show that the biggest difference in market value was observed between the basic variant and the fourth variant (18.1\%). The smallest difference of approximately $8.8 \%$ was between the basic variant and the first variant (Figure 4 ).

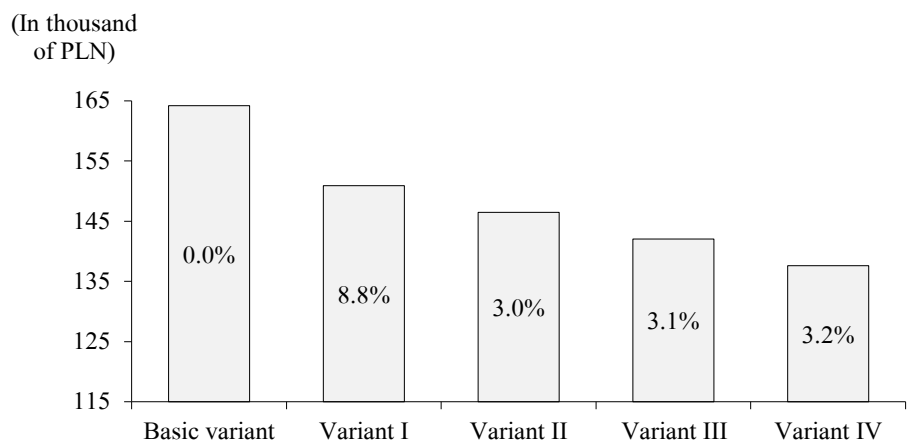

Figure 4. The assessment of the influence of the adopted variant of the technical condition of the building on the market value of a cooperative ownership right to the sample residential apartment

Source: own elaboration. 
Undoubtedly, the technical condition of a building is only one of the attributes affecting the market value of a property. Considering the fact that a market value reflects the expectations as to satisfying the user's needs, despite a diverse vision of life, two main dimensions of social expectations can be observed on the property market, i.e. the expected housing status, e.g. in terms of prestige of the surrounding area, as well as expectations as to the dwelling quality in the 'physical' sense. While the housing status has a rather intuitive character, the dwelling quality is of a more tangible character (measurable).

The housing status is the expression of the inhabitants' living quality (including the neighbourhood safety), affluence, culture, religion, but also the fashion for a particular area. The dwelling quality is influenced by its measurable (physical) attributes, i.e. the appearance of a building (including the number of stories, technical condition, construction technology of a building), dwelling's surface area, functional layout, etc.

The housing status in a given social group is of a discretionary character (fashion), and may be independent of the dwelling quality. There is, however, an acceptable level of the dwelling quality (desirable), below which, irrespective of the housing status, the dwelling is considered as sub-standard (undesirable).

An analysis of the mutual influence of the dwelling quality and the housing status, based on the example of the city of Hanoi in Vietnam, was carried out by Phei Wakely (2000). The authors proposed a universal 'status-quality' theory, in which for a given socio-economical setting, there is a threshold of an acceptable dwelling quality, below which the property is classified as of a worse quality or undesirable.

At the lower levels of property prices, the dwelling quality is a dominating factor, and the dwelling is treated as a useful consumer good providing mainly a shelter to the users, while at the higher price levels, we talk about the exchange value of a property as a favourable investment.

The mutual interaction between these two components, i.e. the housing status and the dwelling quality, is of a local character, and each time requires an individual testing. It is not possible to set clear and time-constant boundaries between the desirable and undesirable zones, especially when it comes to the housing status, which may be independent of the physical distance to the city centre.

There exists, however, a theoretical boundary (threshold) of the 'physical' dwelling quality, above which the condition of the housing cannot be improved further in a rational way. Despite the clear physical quality boundary, the housing status may be improved though (e.g. due to fashion for a given location), which is illustrated by Figure 5. In this figure, $D Q$ stands for the dwelling quality while $H S$ means the housing status. 


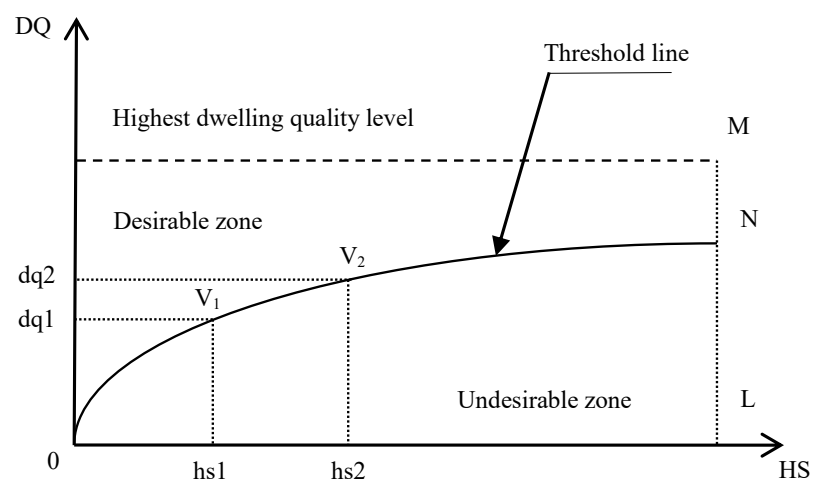

Figure 5. Dwelling quality and Housing status

Source: own elaboration based on Phe and Wakely (2000).

The aim of this paper is to study the influence of the quality of the technical construction on a property value, and the 'status-quality' theory proposed by the authors (Phe, Wakely, 2000) constitutes a discussion on a property value in a social dimension, taking into account the technical aspect of the dwelling quality as well.

\section{Conclusions}

The article presents methods of determining the degree of technical wear of buildings used by real estate appraisers to assess their technical condition in the process of appraisal of the market value of residential apartments. Based on the analysis of five approaches in the socalled time methods, two approaches in the average weighted method, and the mixed approach (the average weighted in the time function with the replacement of building elements), various values of the degree of technical wear were obtained. To evaluate the technical condition of the sample building, the value estimated using the mixed approach was used, and then the market value of the selected apartment in this building was estimated using the so-called basic variant and four other variants of the technical condition.

The varied results may prove that the appraisers' discretion of the assessment of the technical condition of buildings may contribute to misinterpreted market value appraisals. On the other hand,the awareness of different assessment results depending on the adopted assessment method may be a prerequisite to the managers' rational renovation-related or the building-liquidationrelated decisions. However, as indicated by Foryś (2004), the criteria followed by owners/ managers when making rational economic decisions in order to prevent the decrease in property 
value due to technical wear, are complex. Besides economic and financial reasons, a property owner/manager is also limited by legal regulations, urban, conservation, and planning factors, as well as by emotional aspects displayed by dwellers. Therefore, a qualitative improvement of the state of housing resources, including introduction of modern technologies in housing construction, could contribute to the development of the housing market in Poland in terms of economic factors, or the so-called endogenous determinants of development (Foryś, 2013).

\section{References}

Bajno, D. (2013). Rewitalizacja konstrukcji budowlanych w obiektach zabytkowych. Rozprawy nr 171. Bydgoszcz: Uniwersytet Technologiczno-Przyrodniczy im. Jana i Jędrzeja Śniadeckich w Bydgoszczy.

Baranowski, W. (2000). Zużycie obiektów budowlanych oraz podstawowe nazewnictwo budowlane. Warszawa: Wacetob.

Biuletyn Cen Obiektów Budowlanych. Cz. 1 - obiekty budowlane (2012). Zeszyt 32 (1358) Wydawnictwo Sekocenbud.

Foryś, A. (2004). Prace konserwacyjne i remontowe $w$ obiektach budowlanych. In: A. Bryx (ed.), Wprowadzenie do zarzadzania nieruchomościa. Warszawa: Poltext.

Foryś, I. (2008). Nieruchomość jak obiekt techniczny. In: J. Hozer (ed.), Wycena nieruchomości. Szczecin: Katedra Ekonometrii i Statystyki US, IADiPG.

Foryś, I. (2013). Społeczno-gospodarcze determinanty rozwoju rynku mieszkaniowego

w Polsce. Szczecin: Wydawnictwo Naukowe Uniwersytetu Szczecińskiego.

Kucharska-Stasiak, E. (2010). Odwzorowanie cech nieruchomości w cenach i skutki dla procesu wyceny. Studia i Materiały Towarzystwa Naukowego Nieruchomości, 18 (3).

Phe, H.H., Wakely, P. (2000). Status, Quality and the Other Trade-off: Towards a New Theory of Urban Residential Location. Urban Studies, 37 (1).

Powszechne Krajowe Zasady Wyceny (PKZW). Warszawa: Polska Federacja Stowarzyszeń Rzeczoznawców Majątkowych.

Rozporządzeniu Rady Ministrów z dnia 29 czerwca 2005 r. w sprawie powszechnej taksacji nieruchomości (Dz.U. nr 131, poz. 1092 ze zm.).

Ziembicka, B. (2013). Wycena nieruchomości. In: M. Nowak, T. Skotarczak (eds.), Podstawy gospodarowania nieruchomościami. Warszawa: CeDeWu.

Baza danych transakcyjnych Walor. 